\title{
Amino Acids May Have Protective Effects on Salivary Glands of 5-FU-administered Mice
}

\author{
RIEKO FUJIWARA, KOJI HARADA, TARANNUM FERDOUS and KATSUAKI MISHIMA
}

Department of Oral and Maxillofacial Surgery, Yamaguchi University Graduate School of Medicine, Ube, Japan

\begin{abstract}
Background/Aim: This study aimed to identify the most useful components of Elental ${ }^{\circledR}$ in the treatment of 5fluorouracil (FU)-induced mucositis and salivary gland atrophy in mice. Materials and Methods: Mice (except the control group) were intraperitoneally injected with 5-FU. The mice received saline (control group and 5-FU group), dextrin (Dextrin group), amino acids (17AA group), or

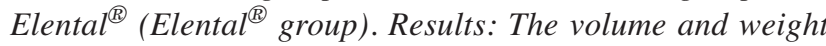
of salivary glands was higher in 17AA and Elental ${ }^{\circledR}$ groups compared to 5-FU group. The number of mucous glands was higher, whereas the number of damaged granular ductal epithelial cells was lower in the salivary glands of all groups except the 5-FU group. Salivation was also decreased in the 5-FU group compared to the other groups. Conclusion: Amino acids could be the most effective components of Elental $^{\circledR}$ for protecting mouse salivary glands from 5-FUinduced atrophic changes, and might be useful in the treatment of oral mucositis in cancer patients.
\end{abstract}

Oral mucositis is one of the adverse reactions to chemotherapy and radiotherapy which increases the duration of hospitalization, cost of care and survival rates in cancer patients $(1,2)$. Patients suffer a wide range of complications including acute oral pain, infection, bleeding, bacteremia, sepsis, salivary gland atrophy and xerostomia that can compromise nutritional intake, salivary gland functions, body weight and oral hygiene in cancer patients, especially in immunosuppressed patients (1-4). There is limited knowledge regarding the detailed mechanism of chemotherapy- or

This article is freely accessible online.

Correspondence to: Dr. Koji Harada, Department of Oral and Maxillofacial Surgery, Yamaguchi University Graduate School of Medicine, 1-1-1 Minamikogushi, Ube 755-8505, Japan. Tel: +81 836222297, Fax: +81 836222298, e-mail: harako@yamaguchiu.ac.jp

Key Words: Salivary gland, elemental diet, amino acid, 5flurouracil, oral mucositis. radiotherapy- induced mucositis. Approximately $80 \%$ of cancer patients receiving 5-fluorouracil (5-FU) - based chemotherapy suffer from mucositis, whereas $20 \%$ of them experience severe mucositis (5). Antineoplastic drugs may damage basal epithelium and mucosal cells in the oral cavity, oropharynx, gut and skin; as well as stem cells (6-9). Salivary gland functions and saliva volume play an important role in modulating the health of the oral cavity and oropharynx (3). Saliva proteins including mucins are essential for lubrication, while lactoferrin, defensins and immunoglobulin A ( $\operatorname{Ig} \mathrm{A})$ have antimicrobial and protective effect (10). It is a wellestablished fact that chemotherapeutic agents including 5-FU, taxanes and platinum derivatives injure salivary gland tissues, and decrease saliva secretion volume as well as saliva proteins, which might contribute to the occurrence and severity of oral mucositis $(3,11-13)$. The efficacy of the available therapies for the prevention or treatment of chemotherapy-induced mucositis is still limited (14-17). And most of these agents are not aimed to protect salivary glands and salivary gland functions against the adverse effects of chemotherapy. Therefore, finding new strategies to alleviate adverse reactions of anticancer agents and to develop novel therapies for mucositis are urgently needed.

ELENTAL $^{\circledR}$ (Ajinomoto Pharmaceutical Ltd., Tokyo, Japan) is an elemental diet (ED), which is composed of several components including amino acids, carbohydrate, vitamins, minerals and fat $(18,19)$. ELENTAL ${ }^{\circledR}$ contains Dextrin $(63.41 \mathrm{~g} / 80 \mathrm{~g})$ and a mixture of seventeen different amino acids $(14.1 \mathrm{~g} / 80 \mathrm{~g}$ with particularly high amount of Lglutamine $(1,932 \mathrm{mg} / 80 \mathrm{~g})$ and L-leucine $(899 \mathrm{mg} / 80 \mathrm{~g})$ (Table I). This ED is used in Japan for decades as a treatment for malnutrition in cancer patients, and also used globally in the treatment of Crohn's disease (19-22). Several clinical studies showed the beneficial effects of Elental ${ }^{\circledR}$ against chemotherapy-induced mucositis in cancer patients $(23,24)$. Animal studies have shown that ED with glutamine may protect the gut from chemotherapeutic agents and radiation, and can help in the treatment of chemotherapy-induced mucositis and dermatitis $(7,9,25,26)$. We also reported the healing effects of Elental ${ }^{\circledR}$ against chemotherapy-induced mucositis and dermatitis in head and neck cancer patients 


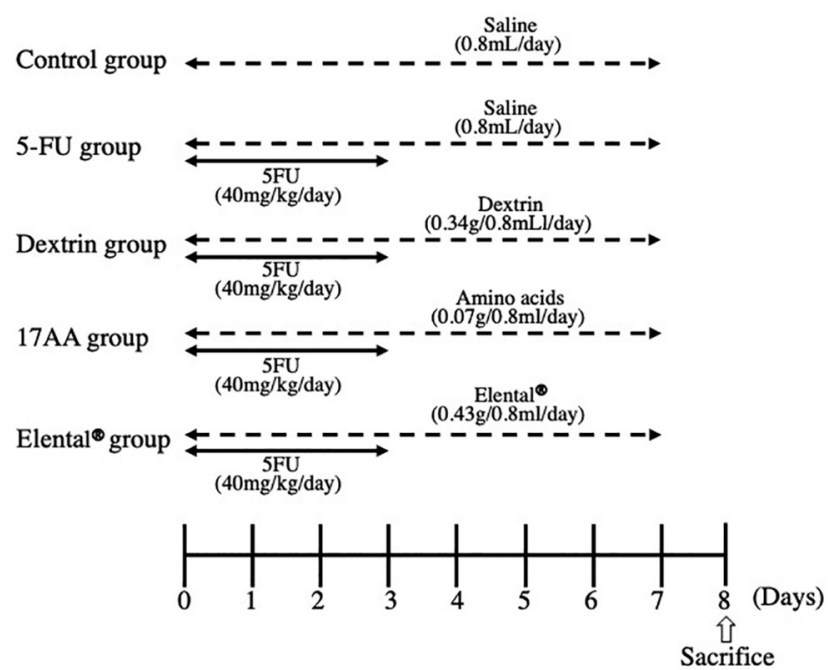

Figure 1. Experimental schedule. All mice (except those in the Control group) received $5-F U(40 \mathrm{mg} / \mathrm{kg} /$ day) intraperitoneally for 4 days (from day 0 to day 3). The Control group and the 5-FU group mice received saline orally $(0.8 \mathrm{ml} /$ day $)$, the Elental ${ }^{\circledR}$ group received Elental ${ }^{\circledR}(0.43$ $\mathrm{g} / 0.8 \mathrm{ml} /$ day $)$, the Dextrin group received $(0.34 \mathrm{~g} / 0.8 \mathrm{ml} /$ day $)$ and the 17AA group mice received a mixture of 17 kinds of amino acids $(0.07$ $\mathrm{g} / 0.8 \mathrm{ml} /$ day) orally for 8 days (day 0 to day 7). The mice were sacrificed on day 8.

$(27,28)$. However, the components of Elental ${ }^{(\mathbb{B})}$ are most useful in the treatment of 5-FU-induced mucosistis were not identified; and whether Elental ${ }^{\circledR}$ can protect salivary glands against 5-FU-induced atrophic changes in patients suffering from oral mucositis were not identified.

In the present study, we used an animal model to identify the most useful components of Elental ${ }^{\circledR}$ in the treatment of 5-FU-induced mucosistis. Moreover, we examined whether Elental ${ }^{\circledR}$ or Elental ${ }^{\circledR}$ components alleviates the adverse reactions associated with cancer chemotherapy including 5FU-induced salivary gland atrophy and salivary gland functions in mice.

\section{Materials and Methods}

Animals. Ten-week-old female ICR mice were obtained from CLEA Japan Inc. (Tokyo, Japan). Mice were housed in a controlled pathogen-free environment in accordance with the Guidelines for Animal Experimentation of Yamaguchi University, Ube, Japan. They were adapted in that environment for one week before the experiment. They were provided with food and water ad libitum. All animal experiments conformed to the guidelines and were approved by the Animal Experimentation committee of Yamaguchi University (approval no. 55-017).

Induction of atrophic changes in mouse salivary glands by 5-FU and assessment of the protective effects of Elental ${ }^{\circledR}$ or Elental ${ }^{\circledR}$ components. Fifteen mice were divided into five groups (Control group, 5-FU group, Dextrin group, 17AA group and Elental ${ }^{\circledR}$ group; $\mathrm{n}=3$ ) on day 0 (time of grouping is referred to as day 0 ). Mice of
Table I. Composition of Elental ${ }^{\circledR}$.

\begin{tabular}{|c|c|c|}
\hline Composition & $\begin{array}{c}\text { Amount } \\
\text { (one package: } \\
80 \mathrm{~g} \text { ) }\end{array}$ & $\begin{array}{c}\text { Amount } \\
\text { (for feeding mice: } \\
0.43 \mathrm{~g} / \text { day) }\end{array}$ \\
\hline Dissolved into & $300 \mathrm{ml}$ water & $0.8 \mathrm{ml}$ water \\
\hline Energy (kcal) & 300 & 1.6 \\
\hline \multicolumn{3}{|l|}{ Carbohydrate (g) } \\
\hline Dextrin & 63.41 & 0.34 \\
\hline \multicolumn{3}{|l|}{ Fat (g) } \\
\hline Soy bean oil & 0.51 & 0.003 \\
\hline Amino acid total (g) & 14.1 & 0.07 \\
\hline \multicolumn{3}{|l|}{ Amino acid (mg) } \\
\hline L-Isoleucine & 642 & 3.424 \\
\hline L-Leucine & 899 & 4.79 \\
\hline Lysine hydrochloride & 888 & 4.73 \\
\hline L-Methionine & 648 & 3.45 \\
\hline L-Phenylalanine & 871 & 4.64 \\
\hline L-Threonine & 523 & 2.79 \\
\hline L-Tryptophan & 151 & 0.80 \\
\hline L-Valine & 701 & 3.74 \\
\hline $\begin{array}{l}\text { L-Histidine hydrochloride } \\
\text { monohydrate }\end{array}$ & 501 & 2.67 \\
\hline L-Arginine hydrochloride & 1,125 & 6 \\
\hline L-Alanine & 899 & 4.79 \\
\hline $\begin{array}{l}\text { L-Aspartic acid } \\
\text { magnesium potassium }\end{array}$ & 1,036 & 5.52 \\
\hline $\begin{array}{l}\text { L-Aspartic acid sodium } \\
\text { monohydrate }\end{array}$ & 867 & 4.62 \\
\hline L-Glutamine & 1,932 & 10.30 \\
\hline Aminoacetic acid & 505 & 2.69 \\
\hline L-Proline & 630 & 3.36 \\
\hline L-Serine & 1,159 & 6.18 \\
\hline L-Tyrosine & 110 & 0.58 \\
\hline $\begin{array}{l}\text { Branched-chain amino } \\
\text { acids or BCAA (mg) }\end{array}$ & 2,242 & 11.95 \\
\hline
\end{tabular}

each group had almost the same mean body weight. Figure 1 shows the experimental schedule. Twelve mice (except the Control group) were treated with intraperitoneal injections of 5-FU (40 mg/kg/day, Kyowa Hakko Kirin Co., Ltd., Tokyo, Japan) for 4 days (from day 0 to day 3) to induce atrophic changes in the salivary glands. The Control and 5-FU groups of mice received saline orally $(0.8 \mathrm{ml} /$ day $)$ whereas the Elental ${ }^{\circledR}$ group received Elental ${ }^{\circledR}(0.43 \mathrm{~g} / 0.8 \mathrm{ml} /$ day, Ajinomoto) orally for 8 days (day 0 to day 7). Table I shows the components of $0.43 \mathrm{~g}$ Elental ${ }^{\circledR}$.The Dextrin group received dextrin of the Elental ${ }^{\circledR}$ component $(0.34 \mathrm{~g} / 0.8 \mathrm{ml} /$ day, Ajinomoto $)$ and the 17AA group received a mixture of 17 amino acids present in Elental ${ }^{\circledR}$ (total amount $0.07 \mathrm{~g} / 0.8 \mathrm{ml} /$ day, Ajinomoto) orally for 8 days (day 0 to day 7). The amount of Dextrin and 17 amino acids for each day was that of $0.43 \mathrm{~g}$ Elental ${ }^{\circledR}$ (Table 1). Body weight was measured before administration of 5-FU, saline, dextrin, amino acids or Elental ${ }^{\circledR}$ from day 0 to day 8 . The experiment was terminated on day 8 and all the mice were sacrificed by cervical dislocation. Salivary glands (the submandibular gland and sublingual gland) were collected, measured and weighed on day 8 soon after sacrifice, and were fixed in $4 \%$ neutral buffered 
A
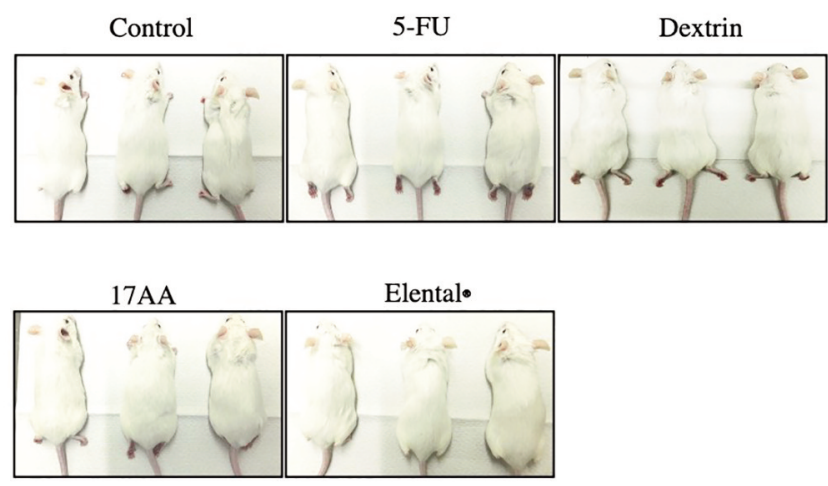

B (g)



Figure 2. Effect of Elental ${ }^{\circledR}$ or Elental ${ }^{\circledR}$ components on mice body weight and morphology. (A) Photos of mice. Notable macroscopical changes were not observed among the groups. (B) Change of body weight. 5-FU, Elental ${ }^{\circledR}$ or Elental ${ }^{\circledR}$ component did not affect mouse body weight. No significant difference of body weight was observed among the groups. Bars, SD.

paraformaldehyde for histological analysis. The volume of the salivary glands was calculated by the following formula: $0.4 \times$ length (L) $\times$ width $\left(\mathrm{W}^{2}\right)$.

Hematoxylin and eosin (HE) staining and observation. After the salivary glands were fixed in $4 \%$ neutral buffered paraformaldehyde at $4^{\circ} \mathrm{C}$ for $24 \mathrm{~h}$, samples were embedded in paraffin. The $4 \mu \mathrm{m}$-thick tissue sections were subjected to HE staining. The tissue sections were immersed in xylene followed by graded ethanol (100\% 70\%) and then washed with tap water at room temperature. Then, they were immersed in hematoxylin for $10 \mathrm{~min}, 1 \%$ acid-ethanol for 30 $\mathrm{s}, 1 \%$ ammonia water for $30 \mathrm{~s}$, and thoroughly washed under running tap water. The sections were then treated with eosin for 1 min, and were subsequently dehydrated in graded ethanol (70\% 100\%) and xylene. After clearing the section with Histoclear (National Diagnostics, Atlanta GA, USA), the slides were mounted with glass coverslips using DPX mounting medium (Sigma-Aldrich; Merck KGaA, Darmstadt, Germany). Then, the number of mucous glands or damaged granular ductal epithelial cells was counted in 10 randomly selected areas per tissue section at 200-fold magnification using a fluorescence microscope (BX51; Olympus Corporation, Tokyo, Japan). The results are expressed as the mean percentage \pm SD.

Salivary secretion induced by cholinergic agonists. Total saliva was collected from each mouse just before sacrifice according to the method of Matsui et al. (29). Animals were fasted for 5 to $7 \mathrm{~h}$ before saliva collection, which was performed between 3:00 and 6:00 p.m. An anesthetic combination $[0.3 \mathrm{mg} / \mathrm{kg}$ of medetomidine (Domitol, Meiji Seika Pharma Co., Ltd., Tokyo, Japan), 4.0 mg/kg of midazolam (Dormicum, Astellas Pharma Inc., Tokyo, Japan), and $5.0 \mathrm{mg} / \mathrm{kg}$ of butorphanol (Vetorphale, Meiji Seika Pharma Co., Ltd.)] was used as a general anesthesia and was injected intraperitoneally. Then, pilocarpine hydrochloride $(1.0 \mathrm{mg} / \mathrm{kg}$, FUJIFILM Wako Pure Chemical Corporation, Osaka, Japan) was dissolved in saline and injected subcutaneously in anesthetized mice to stimulate salivation. Each saliva sample was collected $15 \mathrm{~min}$ and 30 min after pilocarpine stimulation from the oral cavity by a surgical swab, and the weight of the saliva sample was measured by subtracting the weight of the dry surgical swab from the weight of the saliva containing swab.
Statistical analysis. All data are expressed as means \pm standard deviation. All data of each treatment group were compared with the 5-FU group using a Mann-Whitney $U$-test, and $p$-values were based on Mann-Whitney $U$-test. The differences were considered to be statistically significant when $p<0.05$. All statistical analyses were conducted using StatView v.5.0J software (SAS Institute, Inc., Cary, NC, USA).

\section{Results}

The rate of body weight change. We could not detect any notable macroscopical changes in the animals between the different treatment groups and 5-FU group (Figure 2A). There was no a significant difference of body weight among the groups during the experiment (Figure 2B).

The size and weight change of salivary glands. Decreased saliva secretion is associated with oral mucositis in patients receiving cancer chemotherapy (30). In this study, we evaluated the size, volume and weight of salivary glands of mice after 5-FU administration and treatment with Elental ${ }^{\circledR}$ or Elental ${ }^{\circledR}$ components. The size of salivary glands was the smallest in the 5-FU group. The Dextrin group had the second smallest and the control group had the third smallest salivary glands (Figure 3A). The size and volume of salivary glands was comparatively bigger in the 17AA group and Elental ${ }^{\circledR}$ group than all the other groups (Figure $3 \mathrm{~A}$ and $\mathrm{B}$ ). The average volume of the salivary gland was $123 \pm 20.1$ $\mathrm{mm}^{3}$ in the Control group, $63.3 \pm 17.8 \mathrm{~mm}^{3}$ in the 5 -FU group, $87.4 \pm 31.0 \mathrm{~mm}^{3}$ in the Dextrin group, $167.8 \pm 34.7$ $\mathrm{mm}^{3}$ in the 17AA group, and $148.8 \pm 30.2 \mathrm{~mm}^{3}$ in the Elental ${ }^{\circledR}$ group (Figure 3B). Figure 3C shows that the weight of the salivary glands was higher in the Control group, Dextrin group, 17AA group and Elental ${ }^{\circledR}$ group than that in the 5-FU group. The salivary gland weight of Elental ${ }^{\circledR}$ group was the heaviest, and the next heaviest was that of the 17AA group (Figure 3C). 
A

Control

$5-\mathrm{FU}$

Dextrin

17AA

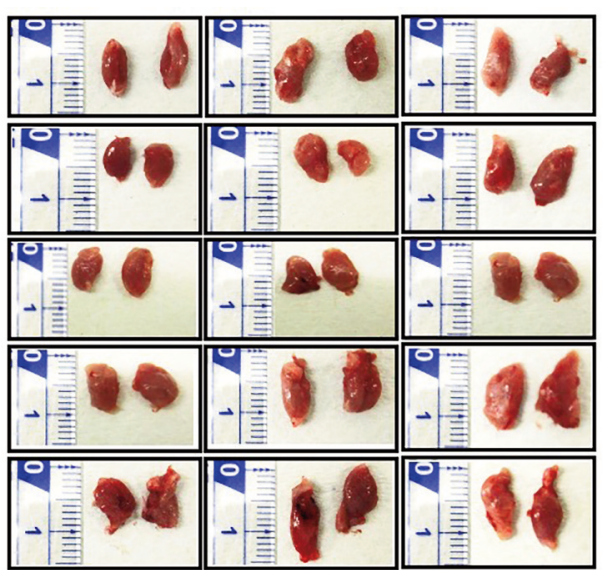

C

$(\mathrm{mm}$ scale; 10 lines $=1 \mathrm{~cm})$
B

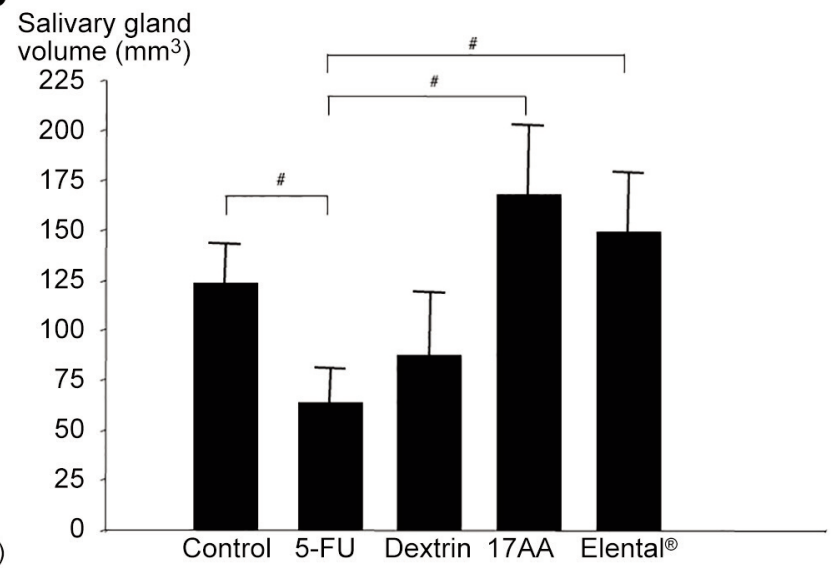

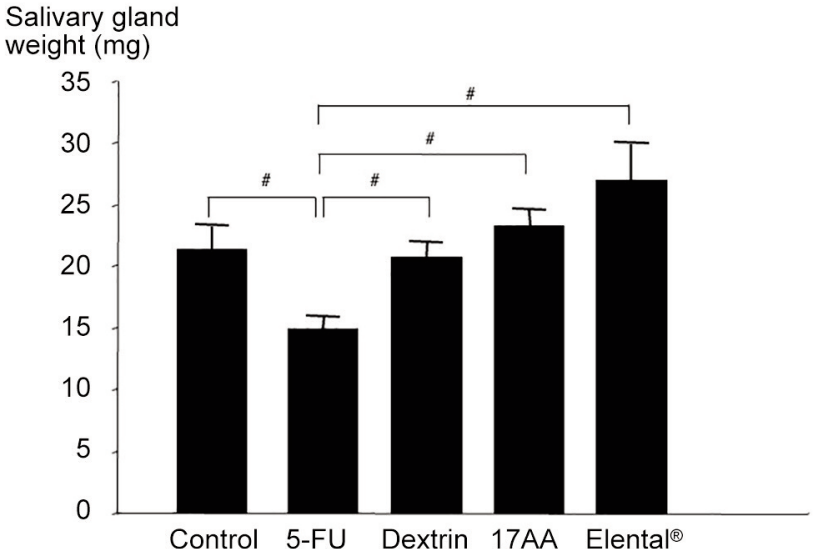

Figure 3. Effect of Elental ${ }^{\circledR}$ or Elental ${ }^{\circledR}$ components on salivary glands. (A) Photos of salivary glands. The size of salivary glands was the lowest in the 5-FU group. (B) Change of salivary glands volume. The volume of salivary glands was greater in the 17AA and Elental ${ }^{\mathbb{B}}$ groups than all the other groups. ${ }^{\#} p<0.01$; compared to the 5-FU group (Mann-Whitney U-test). (C) Change of salivary glands weight. The weight of salivary glands was higher in all groups than that in the 5-FU group. The salivary gland weight of Elental ${ }^{\mathbb{R}}$ group was the heaviest; the 17AA group had the second heaviest salivary glands. Bars, SD. ${ }^{\#} p<0.01$; compared to the 5-FU group (Mann-Whitney U-test).

Histological change of salivary gland. The histology of salivary glands is shown in Figure 4A. The yellow arrows show the mucous gland area of the salivary glands. The mucocus gland size of the 5-FU group was bigger than all the other groups (Figure 4A). However, the number of mucous glands was higher in the Control group, Dextrin group, 17AA group and Elental ${ }^{\circledR}$ group than that in the 5-FU group (Figure $4 \mathrm{~B})$. Interestingly, the number of mucous glands was the highest in the 17AA group and Elental ${ }^{\circledR}$ group (Figure 4B). Figure 4C shows that, the 5-FU group had the highest number of damaged granular ductal epithelial cells, and control group had the lowest number. The number of damaged granular ductal epithelial cells was markedly lower in the Elental ${ }^{\circledR}$ and 17AA groups than in the Dextrin and 5-FU groups. Moreover, we could notice the incidence of disappearance or atrophy of granular ductal epithelial cells (yellow arrows) in 5-FU treated animals in HE stained tissues (Figure 4C).
Changes in saliva secretion pattern. We evaluated the salivary gland function of different mice groups by measuring salivation stimulated by subcutaneous injection of pilocarpine hydrochloride $(1.0 \mathrm{mg} / \mathrm{kg})$ in anesthetized mice. Notably, the salivary response was reduced in the 5-FU group. In contrast, salivation was increased in the 17AA group and Elental ${ }^{\circledR}$ groups compared to the 5-FU group at 15, and $30 \mathrm{~min}$ after pilocarpine stimulation. However, salivation did not increase significantly in the Dextrin group (Figure 5).

\section{Discussion}

In this study, we investigated the efficacy of Elental ${ }^{\circledR}$ or Elental ${ }^{\circledR}$ components against 5-FU-induced mucositis that caused salivary gland atrophy and dysfunction. Saliva, a mixture of water, ions and proteins is produced by three pairs 


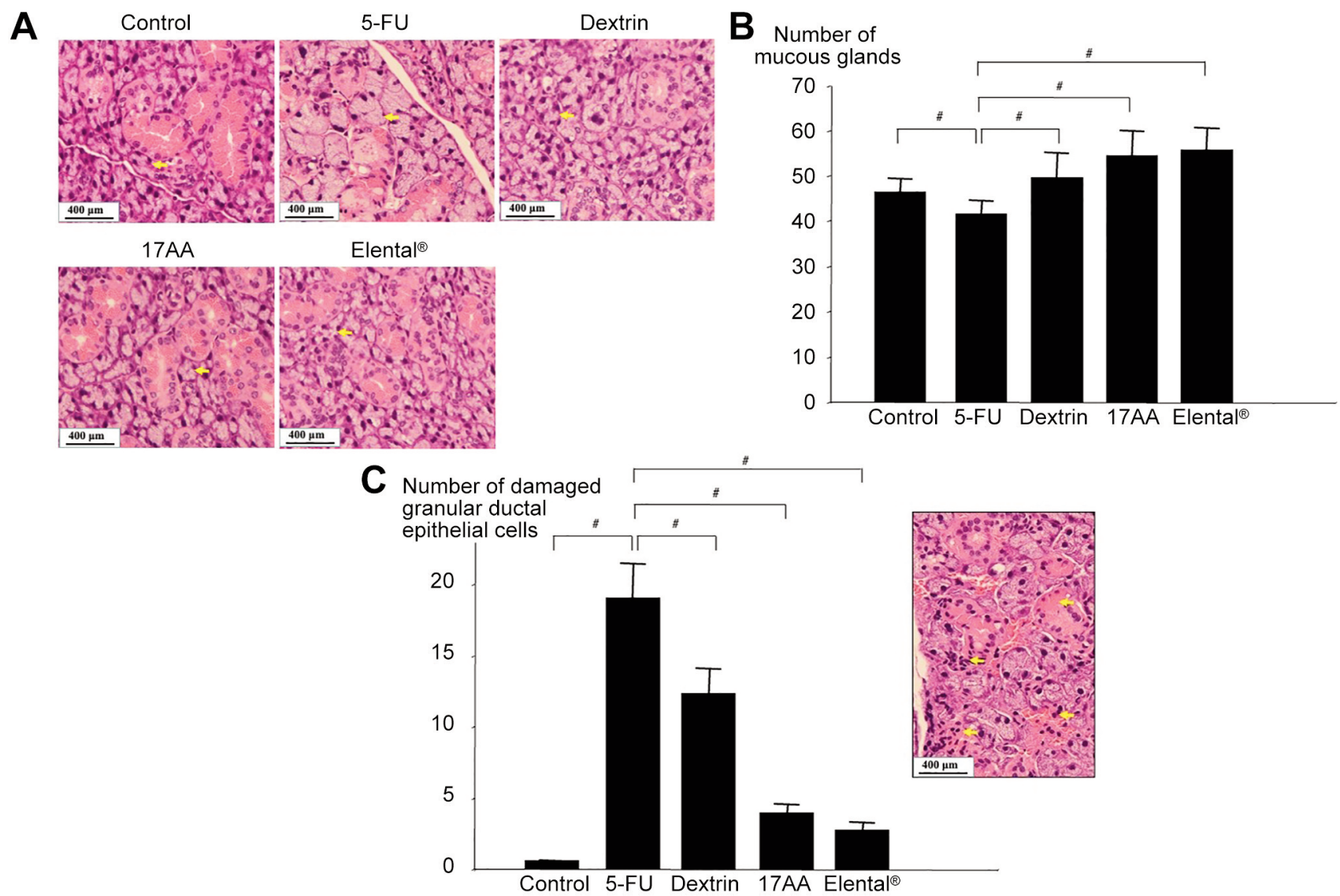

Figure 4. Histological changes of salivary glands in mice. (A) HE staining. Mucous gland size of the 5-FU group was bigger than that of the other groups. The yellow arrows show the mucous gland area of salivary gland. (B) Change of mucous gland number. The number of mucous glands was higher in the Control, Dextrin, 17AA and Elental ${ }^{\circledR}$ groups than that in the 5-FU group, whereas the 17AA and Elental ${ }^{\circledR}$ groups showed the highest number. ${ }^{\#} p<0.01$; compared to the 5-FU group (Mann-Whitney U-test). (C) Change of damaged granular ductal epithelial cell number. The number of damaged granular ductal epithelial cells was higher in the 5-FU group than in all groups, and was lowest in the Elental ${ }^{\circledR}$ and $17 A A$ groups. The yellow arrows show the disappearance or atrophy of granular ductal epithelial cells after 5-FU treatment. Bars, SD. \#p<0.01; compared to the 5-FU group (Mann-Whitney U-test).

of major salivary glands. Dysfunction of salivary glands and decreased saliva excretions negatively affect oral mucosal health and oral hygiene $(3,12,13)$. Saliva has several functions including lubrication and protection which is mainly related to proteins (11). Certain chemotherapy regimens and radiotherapy may cause salivary gland dysfunction and clinically significant decrease in salivary flow rates (2-4). Salivary hypofunction has been directly associated with the occurrence and severity of mucositis, and mucositis may also be caused by insufficient antimicrobial factors and mucosal protectants (e.g., lactoferrin, defensins, glycoproteins, IgA, epidermal growth factor, mucins, etc.) (3, 11, 13). Direct contact of chemotherapeutic agents with the oral epithelium might cause mucosal damage through salivary secretions (31). Alternatively, a study demonstrated that lower saliva secretion volumes could be one of the reasons for the higher incidence of 5-FU-induced oral mucositis (13).
Chemotherapy- or chemoradiotherapy- induced oral mucositis increases the risk of malnutrition in cancer patients, which might lead to increased adverse reactions. Elental ${ }^{\circledR}$ contains easily digestible free amino acids, as well as easy-to absorb carbohydrates such as dextrin, and is effective for the maintenance and improvement of nutritional status in malnourished patients (18-20). We have been using Elental ${ }^{\circledR}$ for treating malnutrition in patients undergoing chemotherapy in recent years. Moreover, we observed that Elental ${ }^{\circledR}$ improved chemotherapy-induced oral mucositis (25-28). Based on our previous data, we hypothesized that Elental ${ }^{\circledR}$ or Elental ${ }^{\circledR}$ components may protect salivary glands, preserve saliva secretion volume and alleviate oral mucositis by improving the oral environment. However, the detailed mechanism by which Elental ${ }^{\circledR}$ alleviates oral mucositis is not clear. Therefore, we investigated the efficacy of Elental ${ }^{\circledR}$ in treating of 5-FU-induced salivary gland 


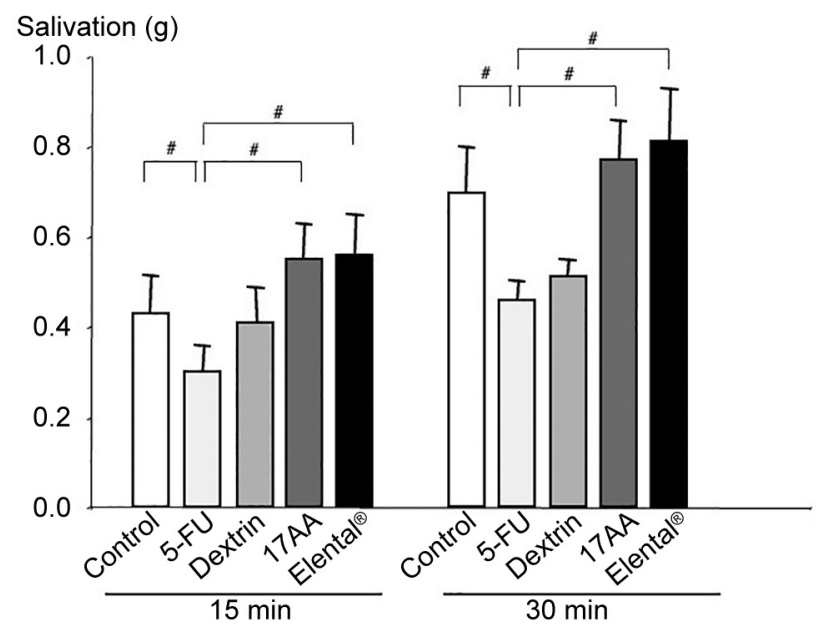

Figure 5. Changes in saliva secretion. The salivary response to pilocarpine was reduced in the 5-FU group. In contrast, pilocarpineinduced salivations were increased in the $17 A A$ and Elental ${ }^{\circledR}$ groups compared to Dextrin group at 15, and 30 min after pilocarpine stimulation. Bars, SD. ${ }^{\#} p<0.01$; compared to the 5-FU group (MannWhitney $U$-test).

atrophy and dysfunction in a mice model and we paid attention to Elental ${ }^{\circledR}$ components, particularly amino acids.

Our findings suggest that, Elental ${ }^{\circledR}$ or Elental ${ }^{\circledR}$ components could alleviate some negative effects of 5-FU associated dysfunction of salivary glands. We observed that the weight of salivary glands and salivation rate were lower in the 5-FU group than in the 17AA (amino acids), Elental ${ }^{\circledR}$ or dextrin groups of mice (Figure 3 and Figure 5). Moreover, the number of mucous glands was lower and the number of damaged granular ductal epithelial cells was higher in the salivary glands of the 5-FU group compared to the other groups (Figure 4). These data indicate that 5-FU-damaged salivary glands were recovered by the administration of Elental ${ }^{\circledR}$, amino acids or dextrin. We observed that these recovery effects were highest in case of the Elental ${ }^{\circledR}$ group. In addition, in all cases, the recovery effects were noticeably higher in 17AA group compared to the Dextrin group. Therefore, we can conclude that amino acids are the most important components of Elental ${ }^{\circledR}$ in ameliorating the adverse reactions of 5-FU-induced atrophic changes in salivary glands.

McCarthy et al. reported that patients receiving 5-FU showing low salivary flow rates at baseline and during therapy had increased risk of mucositis (13). The principal salivary immunoglobulin is $\operatorname{IgA}$. Reduced saliva secretion volume decreases the salivary clearance ability and decreases the concentrations of secretory $\operatorname{IgA}$, which has antibacterial action. Reduced saliva secretion volume decreases the salivary clearance ability and decreases the concentrations of secretory IgA. Moreover, EGF is required in saliva during salivary tissue repair $(32,33)$. This finding may support the hypothesis that bacterial action and end products may be associated with the severity of mucositis (34). Alternatively, it has been reported that reduced salivary flow rates during chemotherapy might help in ameliorate mucositis $(35,36)$. However, our data suggests that Elental ${ }^{\circledR}$ might alleviate oral mucositis because Elental $^{\circledR}$ or Elental ${ }^{\circledR}$ components increased salivation and recovery of salivary glands from 5FU-induced atrophic changes in the mouse model. These findings support our hypothesis that Elental ${ }^{\circledR}$ or Elental ${ }^{\circledR}$ components might promote tissue repair and adjustment of the bacterial flora of the mouth. Further studies are necessary to understand the toxic effects of chemotherapeutic agents on the oral environment for the prevention and treatment of chemotherapy-induced oral mucositis.

In summary, our findings demonstrated that Elental ${ }^{\circledR}$ or Elental ${ }^{\circledR}$ components, particularly amino acids, alleviate adverse reactions of cancer chemotherapy including 5-FUinduced oral mucositis. We conclude that among all the Elental ${ }^{\circledR}$ components, amino acids may have the highest ameliorating effect against 5-FU-induced atrophic changes in salivary glands and salivary gland dysfunction.

\section{Conflicts of Interest}

The Authors declare no conflicts of interest in relation to this study. The Authors are fully responsible for the content of this paper.

\section{Authors' Contributions}

$\mathrm{KH}$ designed the study. RF and $\mathrm{KH}$ performed the experiments. $\mathrm{KH}$ and RF analyzed and interpret the data. $\mathrm{KH}, \mathrm{TF}$ and $\mathrm{RF}$ wrote and revised the manuscript. KM helped in interpretation of data, revised the manuscript and provided valuable suggestions during the study. All Authors have read and approved the final version of the manuscript and are fully responsible for its content.

\section{Acknowledgements}

This study was supported in part by a Grant-in-Aid Scientific Research (grant no. 18K09814) from the Ministry of Education, Culture, Sports, Science and Technology of Japan.

\section{References}

1 Sonis ST: Oral mucositis. Anticancer Drugs 22(7): 607-612, 2011. PMID: 21709615. DOI: 10.1097/CAD.0b013e3283462086

2 Özel O, Ayçiçek A, Kenar F, Aktepe F, Sargin R, Yilmaz MD and Dereköy FS: Histopathologic changes in the rabbit submandibular gland after 5-fluorouracil chemotherapy. Turk $\mathbf{J}$ Med Sci 40(2): 213-220, 2010. PMID: 31411186. DOI: 10.3906/sag-0807-10

3 Epstein JB, Tsang AH, Warkentin D and Ship JA: The role of salivary function in modulating chemotherapy-induced oropharyngeal mucositis: a review of the literature. Oral Surg Oral Med Oral Pathol Oral Radiol Endod 94(1): 39-44, 2002. PMID: 12193891. DOI: 10.1067/moe.2002.126018 
4 Epstein JB, Thariat J, Bensadoun RJ, Barasch A, Murphy BA, Kolnick L, Popplewell L and Maghami E: Oral complications of cancer and cancer therapy: from cancer treatment to survivorship. CA Cancer J Clin 62(6): 400-422, 2012. PMID: 22972543. DOI: $10.3322 /$ caac. 21157

5 Symonds RP: Treatment-induced mucositis: an old problem with new remedies. Br J Cancer 77(10): 1689-1695, 1998. PMID: 9635851. DOI: 10.1038/bjc.1998.279

6 Skubitz KM and Anderson PM: Oral glutamine to prevent chemotherapy induced stomatitis: a pilot study. J Lab Clin Med 127(2): 223-228, 1996. PMID: 8636652. DOI: 10.1016/s00222143(96)90082-7

7 Fox AD, Kripke SA, De Paula J, Berman JM, Settle RG and Rombeau JL: Effect of a glutamine-supplemented enteral diet on methotrexate-induced enterocolitis. JPEN J Parenter Enteral Nutr 12(4): 325-331, 1988. PMID: 3138440. DOI: 10.1177/ 0148607188012004325

8 Ziegler TR, Young LS, Benfell K, Scheltinga M, Hortos K, Bye R, Morrow FD, Jacobs DO, Smith RJ and Antin JH: Clinical and metabolic efficacy of glutamine-supplemented parenteral nutrition after bone marrow transplantation. A randomized, double-blind, controlled study. Ann Intern Med 116(10): 821828, 1992. PMID: 1567096. DOI: 10.7326/0003-4819-116-10821

9 Kyllo RL and Anadkat MJ: Dermatologic adverse events to chemotherapeutic agents, part 1: cytotoxics, epidermal growth factor receptors, multikinase inhibitors, and proteasome inhibitors. Semin Cutan Med Surg 33(1): 28-39, 2014. PMID: 25037256. DOI: 10.12788/j.sder.0060

10 Amerongen AV and Veerman EC: Saliva-the defender of the oral cavity. Oral Dis 8(1): 12-22, 2002. PMID: 11936451. DOI: 10.1034/j.1601-0825.2002.10816.x

11 van Leeuwen SJM, Proctor GB, Laheij AMGA, Potting CMJ, Smits O, Bronkhorst EM, Hazenberg MD, Haverman TM, Brennan MT, von Bültzingslöwen I, Raber-Durlacher JE, Huysmans MCDNJM, Rozema FR and Blijlevens NMA: Significant salivary changes in relation to oral mucositis following autologous hematopoietic stem cell transplantation. Bone Marrow Transplant 56(6): 1381-1390, 2021. PMID: 33420397. DOI: $10.1038 / \mathrm{s} 41409-020-01185-7$

12 Jensen SB, Pedersen AM, Reibel J and Nauntofte B: Xerostomia and hypofunction of the salivary glands in cancer therapy. Support Care Cancer 11(4): 207-225, 2003. PMID: 12673459. DOI: 10.1007/s00520-002-0407-7

13 McCarthy GM, Awde JD, Ghandi H, Vincent M and Kocha WI: Risk factors associated with mucositis in cancer patients receiving 5-fluorouracil. Oral Oncol 34(6): 484-490, 1998 PMID: 9930359. DOI: 10.1016/s1368-8375(98)00068-2

14 Keefe DM, Schubert MM, Elting LS, Sonis ST, Epstein JB, Raber-Durlacher JE, Migliorati CA, McGuire DB, Hutchins RD, Peterson DE and Mucositis Study Section of the Multinational Association of Supportive Care in Cancer and the International Society for Oral Oncology: Updated clinical practice guidelines for the prevention and treatment of mucositis. Cancer 109(5): 820-831, 2007. PMID: 17236223. DOI: $10.1002 /$ cncr.22484

15 Peterson DE, Bensadoun RJ, Roila F and ESMO Guidelines Working Group: Management of oral and gastrointestinal mucositis: ESMO Clinical Practice Guidelines. Ann Oncol 22 Suppl 6: vi78-vi84, 2011. PMID: 21908510. DOI: 10.1093/ annonc/mdr391
16 Bensinger W, Schubert M, Ang KK, Brizel D, Brown E, Eilers JG, Elting L, Mittal BB, Schattner MA, Spielberger R, Treister NS and Trotti AM 3rd: NCCN Task Force Report. prevention and management of mucositis in cancer care. J Natl Compr Canc Netw 6 Suppl 1: S1-21; quiz S22-4, 2008. PMID: 18289497.

17 Scully C, Epstein J and Sonis S: Oral mucositis: a challenging complication of radiotherapy, chemotherapy, and radiochemotherapy. Part 2: diagnosis and management of mucositis. Head Neck 26(1): 77-84, 2004. PMID: 14724910. DOI: 10.1002/hed.10326

18 Online Ajinomoto Products Information. Available at: https://www.ajinomoto.co.jp/company/jp/aboutus/history/chronic le_2014/09.html [Last accessed on August 29, 2021]

19 Yamamoto T, Nakahigashi M, Umegae S, Kitagawa $\mathrm{T}$ and Matsumoto K: Impact of elemental diet on mucosal inflammation in patients with active Crohn's disease: cytokine production and endoscopic and histological findings. Inflamm Bowel Dis 11(6): 580-588, 2005. PMID: 15905706. DOI: 10.1097/01.mib.0000161307.58327.96

20 Johtatsu T, Andoh A, Kurihara M, Iwakawa H, Tsujikawa T, Kashiwagi A, Fujiyama Y and Sasaki M: Serum concentrations of trace elements in patients with Crohn's disease receiving enteral nutrition. J Clin Biochem Nutr 41(3): 197-201, 2007. PMID: 18299716. DOI: $10.3164 /$ jcbn.2007028

21 Yamamoto T, Nakahigashi M, Saniabadi AR, Iwata T, Maruyama Y, Umegae S and Matsumoto K: Impacts of long-term enteral nutrition on clinical and endoscopic disease activities and mucosal cytokines during remission in patients with Crohn's disease: a prospective study. Inflamm Bowel Dis 13(12): 14931501, 2007. PMID: 17879280. DOI: 10.1002/ibd.20238

22 Yamamoto $T$, Nakahigashi $M$, Umegae S, Kitagawa $\mathrm{T}$ and Matsumoto K: Impact of long-term enteral nutrition on clinical and endoscopic recurrence after resection for Crohn's disease: A prospective, non-randomized, parallel, controlled study. Aliment Pharmacol Ther 25(1): 67-72, 2007. PMID: 17229221. DOI: 10.1111/j.1365-2036.2006.03158.x

23 Fukui T, Itoh Y, Orihara M, Yoshizawa K, Takeda H, Kawada S and Yoshioka T: [Elental prevented and reduced oral mucositis during chemotherapy in patients esophageal cancer]. Gan To Kagaku Ryoho 38(13): 2597-2601, 2011. PMID: 22189225.

24 Ogata Y, Takeuchi M, Ishibashi N, Kibe S, Takahashi K, Uchida S, Murakami N, Yahara T and Shirouzu K: [Efficacy of Elental on prevention for chemotherapy-induced oral mucositis in colorectal cancer patients]. Gan To Kagaku Ryoho 39(4): 583587, 2012. PMID: 22504682.

25 Harada K, Ferdous T, Kobayashi H and Ueyama Y: Elemental diet accelerates the recovery from oral mucositis and dermatitis induced by 5 -fluorouracil through the induction of fibroblast growth factor 2. Integr Cancer Ther 17(2): 423-430, 2018. PMID: 28745083. DOI: 10.1177/1534735417721014

26 Harada K, Takenawa T, Ferdous T, Mizukami Y and Mishima K: Elemental diet directly affects chemotherapy-induced dermatitis and raw wound areas. Mol Clin Oncol 13(2): 209-215, 2020. PMID: 32699632. DOI: 10.3892/mco.2020.2050

27 Harada K, Ferdous T, Horinaga D, Uchida K, Mano T, Mishima K, Park S, Hanazawa H, Takahashi S, Okita A, Fukunaga M, Maruta J, Kami N, Shibuya K and Ueyama Y: Efficacy of elemental diet on prevention for chemoradiotherapy-induced oral mucositis in patients with oral squamous cell carcinoma. Support Care Cancer 24(2): 953-959, 2016. PMID: 26248650. DOI: $10.1007 / \mathrm{s} 00520-015-2866-7$ 
28 Harada K, Minami H, Ferdous T, Kato Y, Umeda H, Horinaga D, Uchida K, Park SC, Hanazawa H, Takahashi S, Ohota M, Matsumoto H, Maruta J, Kakutani H, Aritomi S, Shibuya K and Mishima K: The Elental ${ }^{\circledR}$ elemental diet for chemoradiotherapyinduced oral mucositis: A prospective study in patients with oral squamous cell carcinoma. Mol Clin Oncol 10(1): 159-167, 2019. PMID: 30655992. DOI: 10.3892/mco.2018.1769

29 Matsui M, Motomura D, Karasawa H, Fujikawa T, Jiang J, Komiya Y, Takahashi S and Taketo MM: Multiple functional defects in peripheral autonomic organs in mice lacking muscarinic acetylcholine receptor gene for the M3 subtype. Proc Natl Acad Sci U S A 97(17): 9579-9584, 2000. PMID: 10944224. DOI: 10.1073/pnas.97.17.9579

30 Saegusa Y, Ichikawa T, Iwai T, Goso Y, Ikezawa T, Nakano M, Shikama N, Saigenji K and Ishihara K: Effects of acid antisecretory drugs on mucus barrier of the rat against 5fluorouracil-induced gastrointestinal mucositis. Scand J Gastroenterol 43(5): 531-537, 2008. PMID: 18415744. DOI: $10.1080 / 00365520701811693$

31 Ishii E, Yamada S, Higuchi S, Honjo T, Igarashi H, Kanemitsu $\mathrm{S}$, Kai $\mathrm{T}$ and Ueda K: Oral mucositis and salivary methotrexate concentration in intermediate-dose methotrexate therapy for children with acute lymphoblastic leukemia. Med Pediatr Oncol 17(5): 429-432, 1989. PMID: 2796859. DOI: 10.1002/mpo. 2950170514

32 Harrison T, Bigler L, Tucci M, Pratt L, Malamud F, Thigpen JT, Streckfus C and Younger H: Salivary sIgA concentrations and stimulated whole saliva flow rates among women undergoing chemotherapy for breast cancer: an exploratory study. Spec Care Dentist 18(3): 109-112, 1998. PMID: 9680920. DOI: 10.1111/ j.1754-4505.1998.tb00914.x
33 Dumbrigue HB, Sandow PL, Nguyen KH and Humphreys-Beher MG: Salivary epidermal growth factor levels decrease in patients receiving radiation therapy to the head and neck. Oral Surg Oral Med Oral Pathol Oral Radiol Endod 89(6): 710-716, 2000. PMID: 10846125. DOI: 10.1067/moe.2000.106343

34 Dens F, Boogaerts M, Boute P, Declerck D, Demuynck H and Vinckier F: Quantitative determination of immunological components of salivary gland secretion in transplant recipients. Bone Marrow Transplant 17(3): 421-423, 1996. PMID: 8704698.

35 Brown RA, Herzig RH, Wolff SN, Frei-Lahr D, Pineiro L, Bolwell BJ, Lowder JN, Harden EA, Hande KR and Herzig GP: High-dose etoposide and cyclophosphamide without bone marrow transplantation for resistant hematologic malignancy. Blood 76(3): 473-479, 1990. PMID: 2378980.

36 Ahmed T, Engelking C, Szalyga J, Helson L, Coombe N, Cook P, Corbi D, Puccio C, Chun H and Mittelman A: Propantheline prevention of mucositis from etoposide. Bone Marrow Transplant 12(2): 131-132, 1993. PMID: 8401358.
Received October 29, 2021

Revised November 25, 2021

Accepted November 29, 2021 